DOI: http://doi.org/10.21698/simi.2018.fp42

\title{
CONSIDERATIONS REGARDING THE CONTROL OF BIOCHEMICAL OXYGEN DEMAND AND CHEMICAL OXYGEN DEMAND FROM DEJ WASTEWATER TREATMENT PLANT
}

\author{
Marius-Daniel Roman, Roxana Mare, Adriana Hadarean
}

Building Services Engineering Department, Technical University of Cluj-Napoca, Boulevard 128-130 December 21 Blvd., 400604, Cluj-Napoca, marius.roman@insta.utcluj.ro, Romania

\begin{abstract}
Biochemical Oxygen Demand (BOD) and Chemical Oxygen Demand (COD) are the most commonly used parameters for the characterization of the organic pollution of wastewaters. Both of these parameters have advantages and disadvantages and the choice usually depends on many factors such as the time period required to determine each one of them. It is essential to obtain a control between BOD and COD for various wastewater treatment plants, to help in the design and operation of these plants. In this paper the modelling results of BOD and COD for an aeration tank from Dej wastewater treatment plant by Matlab/Simulink software program has no significant difference, because the results are close enough to the real ones that allow the user to make a good prediction regarding this parameters. A true validation of these results, including experimental validation of simulations of the entire collecting data was realistic.
\end{abstract}

Keywords: biochemical oxygen demand, chemical oxygen demand, wastewater, simulation, parameters

\section{Introduction}

Wastewater is characterized in terms of physical, chemical and biological composition (Hur et al 2010). Depending on the level of pollutants and local regulations; physical, chemical and biological treatment may be used (Tchobanoglous et al 2003, Cossu et al 2017). Before any wastewater can be treated, it must first be characterized, because knowing the composition of the influent wastewater is essential for successful design and operation of wastewater treatment plants (Sincero \& Sincero 2003). The impact of an effluent or wastewater discharge on the receiving water is predicted by its oxygen demand (Sawyer et al 2003, Ahmed et al 2013). The two most common parameters used to recognize the composition of wastewater are the biochemical oxygen demand (BOD) and the chemical oxygen demand (COD). BOD 5 is a measure of how much dissolved oxygen is consumed by aerobic bacteria in 5 days at $20^{\circ} \mathrm{C}$. It is the broad measure of the strength of the organic matter in a waste stream. The typical range of $\mathrm{BOD}_{5}$ in domestic wastewater ranges is between 100 to $300 \mathrm{mg} / \mathrm{L}$. COD is chemical oxygen demand and is measured chemically by digestion with acid. There exists a definite correlation between the COD and BOD under certain conditions and by determining 


\section{INTERNATIONAL SYMPOSIUM "THE ENVIRONMENT AND THE INDUSTRY", SIMI 2018, PROCEEDINGS BOOK}

the COD, the information about the BOD of the wastewater can be derived, but it is highly waste dependent (Sawyer et al 2003, Khaled \& Gina 2014, Henze et al 2000). These two parameters have advantages and disadvantages and the choice usually depends on many factors such as, the reproducibility of the determinations, time period required location of the test (Evangelou et al 2017). COD analysis estimates the amount of organic matter in wastewater in only three to four hours, rather than the five days required by the $\mathrm{BOD}_{5}$ test and can be used as an alternative. COD results are typically higher than $\mathrm{BOD}_{5}$ values and the ratio between them will vary depending on the characteristics of the wastewater.

In this case for a model is important to have something representative in the design and operation of wastewater treatment systems, it must be possible to evaluate parameter values which are wastewater specific and to estimate concentrations of important components in the influent (West \& Dellana 2008). The first step is to identify the components of relevance in the model. In this case these are BOD and COD. The second step is to identify the biological processes occurring in the system, for example the transformations or the conversions that happen and write mathematical relations that describe the process. The third step is to use a simulation program. In this study was used Matlab/Simulink. Although a number of environmental factors can influence the parameter values, these are specific factors in the wastewater, $\mathrm{pH}$ and temperature.

The purpose of this model is to find a mathematical model able to determine certain effluent levels, for BOD and COD concentrations depending on influent and effluent. Khaled \& Gina (2014) obtained in the case studies, for parameters COD and BOD in different plants of variable types and treatment capacities, that the correlation between $\mathrm{BOD}_{5}$ and $\mathrm{COD}$ is generally linear, except in some rare cases where the relation was polynomial and sometimes doesn't have a definite pattern. However, this rare indefinite pattern might be due to inaccuracy in determination of the $\mathrm{BOD}_{5}$ and COD parameters in such cases. Since the BOD and COD are correlated, the estimation of $\mathrm{BOD}_{5}$ values using the quick $\mathrm{COD}$ test, and plant specific biodegradability index (which is the slope of the plotted correlation) became possible and relatively reliable. Thus, it can be used as a check parameter to evaluate performance for quick action. In order to establish the BOD and COD correlation for a particular existing wastewater, one should have both $\mathrm{COD}$ and $\mathrm{BOD}_{5}$ values for several representative wastewater samples. From graphics the $\mathrm{BOD}_{5}$ values versus the COD values then use the regression analysis to develop the correlation. The plotted $\mathrm{BOD}_{5}$ and $\mathrm{COD}$ figures indicated that there is a clear linear positive correlation for most case studies, which differs from plant to another (Khaled \& Gina 2014).

\section{Materials and Methods}

We consider a tank which has: width $35.1 \mathrm{~m}$ and height of $4.95 \mathrm{~m}$, with the volume of $8947 \mathrm{~m}^{3}$. It was considered as a static system with a piston-type flow with changing parameters as the water moves into the tank.

Were taken into account the following simplifying assumptions: 


\section{INTERNATIONAL SYMPOSIUM "THE ENVIRONMENT AND THE INDUSTRY", SIMI 2018, PROCEEDINGS BOOK}

- All parameters are constant in radial section of the reactor (flow piston type).

- The flow rate is considered constant.

- Flow regime is considered ideal (flow regime shift (type D).

- Density and water temperature are considered constant and have not been taken into account.

- The influence of $\mathrm{pH}$ was not taken into account, which is assumed constant.

- Ammonification was considered constant.

- Biomass concentration in the tank was considered constant (specific death rates, the increase is much smaller than reaction rates).

- The vapour pressure of the water surface was not been considered.

To achieve simulation method was used Matlab/Simulink software. The mathematical model of the aeration tank consists of a system by a differential equation for each parameter to be determined. For numerical solutions of differential equations using the method of integration ODE45 (Dormánd-Prince) with variable step and relative tolerance of $10^{-3}$. For calculation was used Matlab program version 7.14.0.739.

Knowing the size of the tank could calculate the cross section area as follows:

Wetted area is calculated first using the formula:

$$
\mathrm{A}_{\mathrm{u}}=\mathrm{H} \cdot \mathrm{l}
$$

where: $A_{u}$ is the wetted area $\left[\mathrm{m}^{2}\right], \mathrm{H}$ is the height of the tank $[\mathrm{m}]$ and $\mathrm{l}$ is the width of the tank $[\mathrm{m}]$.

Wetted perimeter is then calculated:

$$
\mathrm{P}_{\mathrm{u}}=2 \cdot(\mathrm{H}+\mathrm{l})
$$

where: $P_{u}$ is the wetted perimeter $[\mathrm{m}]$.

This is necessary to determine equivalent diameter, which has the following formula:

$$
\mathrm{D}_{\text {ech }}=4 \cdot \frac{\mathrm{A}_{\mathrm{u}}}{\mathrm{P}_{\mathrm{u}}}
$$

where: $\mathrm{D}_{\text {ech }}$ is the equivalent diameter [m].

Having calculated the equivalent diameter of the cross-sectional area can be calculated:

$$
A=\frac{\pi \cdot\left(D_{e c h}\right)^{2}}{4}
$$

where: A is the cross-sectional area of the tank considered [ $\left.\mathrm{m}^{2}\right]$.

Input flow is known from experimental data and calculated using the above area can cause water flow rate:

$$
\mathrm{w}=\frac{\mathrm{F}}{\mathrm{A}}
$$




\section{INTERNATIONAL SYMPOSIUM "THE ENVIRONMENT AND THE INDUSTRY", SIMI 2018, PROCEEDINGS BOOK}

where: $\mathrm{W}$ is the water flow rate $\left[\mathrm{m}^{3} / \mathrm{h}\right]$ and $\mathrm{F}$ is the experimentally measured water flow $\left[\mathrm{m}^{3} / \mathrm{h}\right]$.

All these equations are part of the mathematical model, namely the algebraic equations of the model.

Differential equations of the model are:

For BOD5:

$$
\frac{\mathrm{dBOD}_{5}}{\mathrm{dt}}=-\mathrm{Y}_{1} \cdot \frac{\left(\mathrm{BOD}_{5}-\mathrm{C}_{\mathrm{i}}\right)}{\mathrm{w}}
$$

For COD:

$$
\frac{\mathrm{dCOD}}{\mathrm{dt}}=-\mathrm{Y}_{2} \cdot \frac{\left(\mathrm{COD}-\mathrm{C}_{\mathrm{i}}\right)}{\mathrm{w}}
$$

where: $\mathrm{dBOD}_{5} / \mathrm{dt}$ is the the changes in biochemical oxygen demand after 5 days, $\mathrm{Y}_{1}$ is the theoretical stoichiometric ration, $\mathrm{Y}_{2}$ is the theoretical stoichiometric ration, $\mathrm{C}_{\mathrm{i}}$ is the standard oxygen concentration $(1.5 \mathrm{mg} / \mathrm{ml})$.

In the last decade, stringent quality standards are being applied to effluent plants, whether by regulatory authorities or environmentally concerned plant management. More often than not now, limits on nitrates, ammonia, phosphates, suspended solids, etc. are applied to outfalls (Turak \& Fsar 2004).

To realise an optimum biological process, it is necessary to assure the best environment for the bacteria. A few important parameters are oxygen, $\mathrm{pH}$ and temperature, as well as suspended solids which indicate the bacteria concentration in the tank. Advanced monitoring of the bacteriological processes based on oxygen, ammonia and nitrate makes it possible to satisfy strict legal regulations and to optimize energy consumption at the same time.

\section{Results and Discussion}

For BOD were obtained 20 simulations with increasing values of inflow starting from $188.88 \mathrm{~m}^{3} / \mathrm{h}$ up to $314.67 \mathrm{~m}^{3} / \mathrm{h}$. Influent flow values and the influent concentrations were taken from experimentally determined data from treatment plant using the analysis method according to SR EN 1899-2/2002 (NTPA-001/2005).

Simulation results from data obtained were compared with those determined experimentally. In the case of biochemical oxygen demand after 5 days was obtained the graph from Figure 1. It may be noted that the data obtained from simulation and the data obtained experimentally keeps tendency, which otherwise have no trend. The data measured at the plant can vary widely from day to day even for the same rate, this being also very difficult to simulate. But with this mathematical model results are close enough to the real ones that allow the user to make a good prediction of biochemical oxygen demand after 5 days, knowing the inflow of water and oxygen concentration standard. 
Table 1. Experimental values for BOD

\begin{tabular}{|c|c|c|c|c|c|c|c|}
\hline \multirow[t]{2}{*}{ Sample } & $\begin{array}{l}\text { Influent } \\
\text { flow }\end{array}$ & $\begin{array}{c}\text { Influent } \\
\text { BOD }\end{array}$ & EffluentBOD & \multirow[t]{2}{*}{ Sample } & $\begin{array}{l}\text { Influent } \\
\text { flow }\end{array}$ & InfluentBOD & $\begin{array}{c}\text { Effluent } \\
\text { BOD }\end{array}$ \\
\hline & $\mathrm{m}^{3} / \mathrm{h}$ & $\mathrm{mg} / \mathrm{l}$ & $\mathrm{mg} / \mathrm{l}$ & & $\mathrm{m}^{3} / \mathrm{h}$ & $\mathrm{mg} / \mathrm{l}$ & $\mathrm{mg} / \mathrm{l}$ \\
\hline 1 & 188.88 & 190 & 4 & 11 & 256.71 & 100 & 14 \\
\hline 2 & 197.42 & 195 & 6 & 12 & 261.33 & 200 & 10 \\
\hline 3 & 201.79 & 140 & 4 & 13 & 262.54 & 125 & 8 \\
\hline 4 & 214.00 & 125 & 6 & 14 & 267.04 & 110 & 8 \\
\hline 5 & 224.17 & 105 & 10 & 15 & 272.63 & 105 & 6 \\
\hline 6 & 226.08 & 150 & 10 & 16 & 281.71 & 70 & 10 \\
\hline 7 & 229.13 & 205 & 10 & 17 & 289.54 & 100 & 10 \\
\hline 8 & 236.29 & 155 & 8 & 18 & 301.17 & 150 & 8 \\
\hline 9 & 244.46 & 160 & 10 & 19 & 302.00 & 125 & 12 \\
\hline 10 & 247.67 & 100 & 6 & 20 & 314.67 & 160 & 10 \\
\hline
\end{tabular}

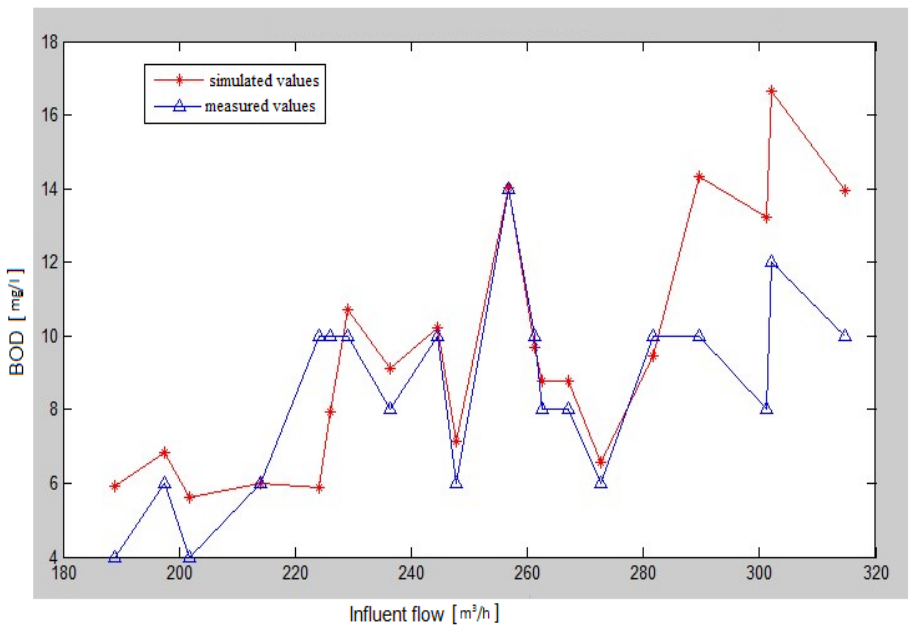

Figure 1. Simulated and measured values of BOD from Dej WWTP

As was shown in the graphic all data were simulated in according to normative NTPA-001/2005, below $25 \mathrm{mg} / \mathrm{l}$, although influent concentrations values were between 70 and $205 \mathrm{mg} / \mathrm{l}$. The dissolved oxygen concentration can be measured by an optical sensor for continuous determination of oxygen (Haimi et al 2009). For COD, were performed 20 simulations for the increasing values of flow starting from $188.88 \mathrm{~m}^{3} / \mathrm{h}$ up to $314.67 \mathrm{~m}^{3} / \mathrm{h}$. Concentration values from the influent and effluent have been determined experimentally by potassium dichromate method according to SR ISO 6060/1996 (NTPA-001/2005). 
Table 2. Experimental values for COD

\begin{tabular}{cccccccc}
\hline \multirow{2}{*}{ Sample } & $\begin{array}{c}\text { Influent } \\
\text { flow }\end{array}$ & $\begin{array}{c}\text { Influent } \\
\text { COD }\end{array}$ & $\begin{array}{c}\text { Effluent } \\
\text { COD }\end{array}$ & Sample & $\begin{array}{c}\text { Influent } \\
\text { flow }\end{array}$ & $\begin{array}{c}\text { Influent } \\
\text { COD }\end{array}$ & $\begin{array}{c}\text { Effluent } \\
\text { COD }\end{array}$ \\
\cline { 2 - 7 } $\mathrm{m}^{3} / \mathrm{h}$ & $\mathrm{mg} / \mathrm{l}$ & $\mathrm{mg} / \mathrm{l}$ & & $\mathrm{m}^{3} / \mathrm{h}$ & $\mathrm{mg} / \mathrm{l}$ & $\mathrm{mg} / \mathrm{l}$ \\
\hline 1 & 188.88 & 674 & 47 & 11 & 256.71 & 422 & 58 \\
2 & 197.42 & 505 & 37 & 12 & 261.33 & 307 & 38 \\
3 & 201.79 & 269 & 29 & 13 & 262.54 & 238 & 48 \\
4 & 214.00 & 307 & 58 & 14 & 267.04 & 269 & 29 \\
5 & 224.17 & 317 & 38 & 15 & 272.63 & 189 & 28 \\
6 & 226.08 & 217 & 19 & 16 & 281.71 & 269 & 48 \\
7 & 229.13 & 490 & 28 & 17 & 289.54 & 378 & 57 \\
8 & 236.29 & 422 & 58 & 18 & 301.17 & 400 & 38 \\
9 & 244.46 & 384 & 38 & 19 & 302.00 & 422 & 38 \\
10 & 247.67 & 211 & 67 & 20 & 314.67 & 355 & 29 \\
\hline
\end{tabular}

The results obtained of the simulation are compared to the experimental ones as was shown in Figure 2. If in the case of biochemical oxygen demand after 5 days the results can vary widely from one day to another day, from a flow or even at the same flow, in case of oxygen concentration determined by the COD also from the influent and effluent varies more than in the previous simulation.

This linearity is present as well in simulation of this parameter, but the trend keeps organized pattern of actual data. However data from simulation is close to the real values and the mathematical model can be used to predict the effluent of the oxygen concentration normally determined experimentally with COD method.

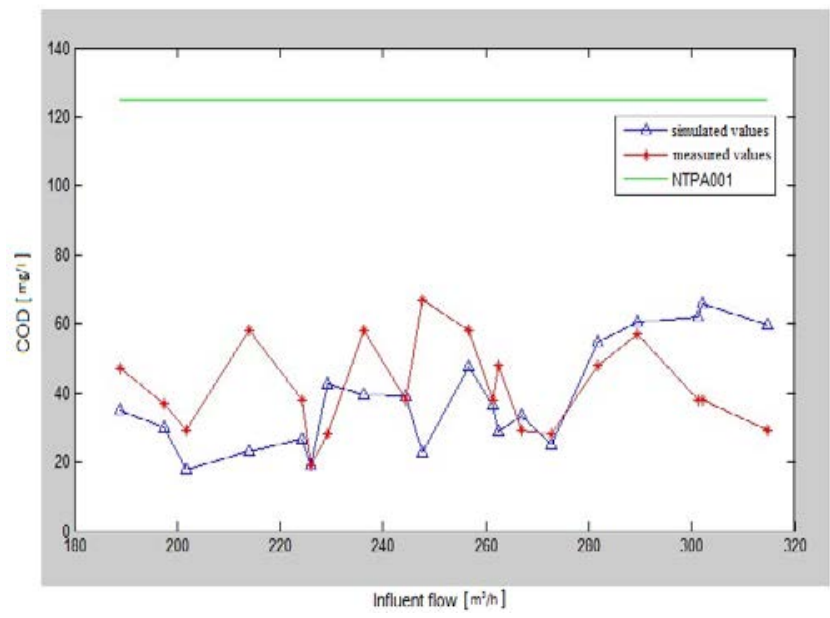

Figure 2. Simulated and measured values of COD from Dej WWTP

All simulation data are below to the maximum allowed by the normative NTPA001/2005, below $125 \mathrm{mg} / \mathrm{l}$. Block diagram of the model in Simulink can be seen in Figure 3. In the left diagram can be seen the three input quantities of inflow in $\mathrm{m}^{3} / \mathrm{h}$ and BOD after 5 days from the entry into the tank and COD from the entry into the tank. The three enter in a multiplier which forwards them to the position $\mathrm{S}$. 


\section{INTERNATIONAL SYMPOSIUM "THE ENVIRONMENT AND THE INDUSTRY", SIMI 2018, PROCEEDINGS BOOK}

After completing the steps in the $\mathrm{S}$ output as is represented in figure 3 , but also are sent to the workspace in the form of a matrix. Simulation time is set to 120 minutes.

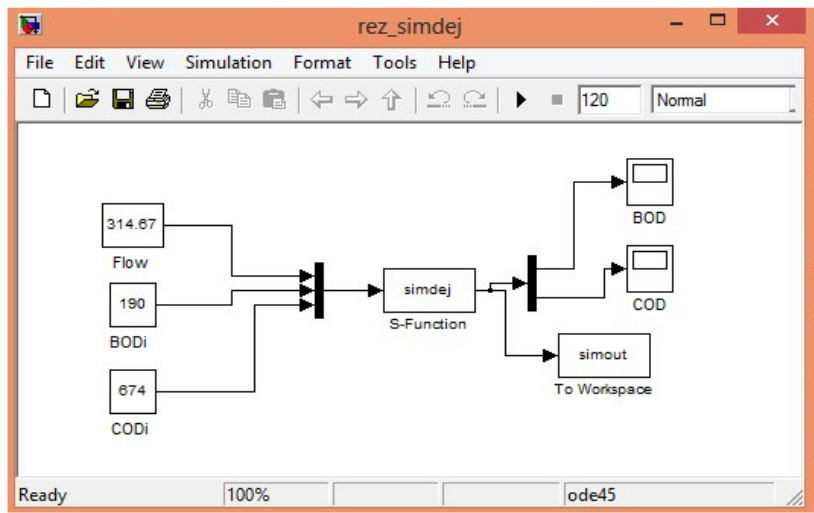

Figure 3. Block diagram of the model in Simulink

Data collected from the wastewater treatment plant keeps a uniform trend, this was underlined by the results of simulations. In simulation we can see a very good overlap of simulated results over determined experimentally, because the tank is rectangular, which is enough close to ideal form.

\section{Conclusions}

In this paper, a procedure for getting a set of solutions for development of a mathematical model must incorporate the major events occurring within a system in a manner which is consistent with established knowledge about that system.

Validated process models can be used for dynamic simulations, for example, with different kinds of input data. In simulations the mathematical equations of process model are solved and the results given. Models and software for simulation have the possibility to control and evaluate the parameters. The presented control strategies use mainly ideal conditions, given the circumstances, for controllers and plant operations.

The formal modelling of systems has been done with a mathematical model, which attempts to find analytical solutions enabling the prediction of the behavior of the system from a set of parameters and initial conditions. Modelling techniques include statistical methods, computer simulation, system identification, and sensitivity analysis; however, one of these is as important as the ability to understand the underlying dynamics of a complex system. Models applied for prediction aim at providing an accurate and fast image of a real systems behavior under different conditions.

Models may be linear with respect to variables or parameters; furthermore, a model can be nonlinear to parameters and linear to variable. Linear models are used frequently, because the analytical solution can be found. For nonlinear models numerical solutions are predominant. Term mechanistic, physiological and white- 


\section{INTERNATIONAL SYMPOSIUM "THE ENVIRONMENT AND THE INDUSTRY", SIMI 2018, PROCEEDINGS BOOK}

box are used to describe that models structure is based on physical, chemical and biological laws.

\section{References}

Ahmed, S, Abdelhalim, H \& Rozaik, E 2013, 'Treatment of primary settled wastewater using anaerobic sequencing batch reactor seeded with activated EM', Civil and Environmental Research, vol. 3, no. 11, pp. 130-136.

Cossu, R, Fantinato, G, Pivato, A \& Sandon, A 2017, 'Further steps in the standardization of $\mathrm{BOD}_{5} / \mathrm{COD}$ ratio as a biological stability index for MSW', Waste Management, vol. 68, pp. 16-23.

Evangelou, A, Chintzios, V, Komilis, D \& Sanchez, A 2017, 'Effect of air flow rate on the dynamic respiration activity of the raw organic fraction of municipal solid wastes', Bioresource Technology, vol. 224, pp. 748-752.

Haimi, H, Mulas, M, Sahlstedt, K \& Vahala, R 2009, 'Advanced operation and control methods of municipal wastewater treatment processes in Finland', Helsinki University of Technology Water and Wastewater, pp. 7-17.

Henze, M, Gujer, W, Mino, TM \& van Loosdrecht 2000, 'Activated sludge models ASM1, ASM2, ASM2d and ASM3’, Scientific and Technical Report, no.9, IWA Publishing, pp. 6-8-16-26.

Hur, J, Lee, BM, Lee, THw \& Park, DH 2010, 'Estimation of biological oxygen demand and chemical oxygen demand for combined sewer systems using synchronous fluorescence spectra.' Sensors, vol.10, no.4, pp. 2460-2471.

Khaled ZA \& Gina, H 2014, 'Correlation between biochemical oxygen demand and chemical oxygen demand for varoius wastewater treatment plants in Egypt to obtain the biodegradability indices', International Journal of Sciences: Basic and Applied Research, vol.13, no.1, pp. 42-48.

NTPA-001/2005, Normative act regarding the determination of limits of loading with pollutants of industrial and town wastewaters at evacuation in natural receptors, 2005.

Sincero, AP \& Sincero, GA 2003, 'Physical-chemical treatment of water and wastewater', IWA Publishing, UK.

Sawyer, CN Parkin, GF \& McCarty, PL 2003, 'Chemistry for Environmental Engineering', $5^{\text {th }}$ ed. New York, McGraw-Hill.

SR EN 1899-2/2002, Determination of biochemical oxygen demand after 5 days (BOD).

SR ISO 6060/1996, Determination of the chemical oxygen demand (COD).

Tchobanoglous, Burton, FL \& Stensel, HD 2003, 'Wastewater Engineering:Treatment And Reuse', Metcalf and Eddy.” $4^{\text {th }}$ edition, New York, McGraw-Hill.

Turak, UG \&. Fsar, HA 2004, 'Research of BOD and COD values of wastewater that contain certain organic materials', A Donor Menderes Univ. $4^{\text {th }} A A C D$ congress Kusadasi-Aydin, Turkey, pp. 177.

West, D \& Dellana, SA 2008, 'Predictive modeling for wastewater applications: linear and nonlinear approaches', Environmental Modelling \& Software, vol. 24, no.1, pp. 96-106. 